\title{
PEACE EDUCATION AND PEACE-BUILDING IN MAINSTREAM EDUCATION SYSTEM
}

\author{
Tayyaba Zarif* \\ Safia Urooj ${ }^{* *}$ \\ Rizwana Munir $^{* * *}$
}

\begin{abstract}
Globally human societies are battling with diverse challenges from socio-cultural apprehension to the wave of religious extremism \& conflicts consequently it is a quite high time for human societies and its stakeholders to come up with the possible applied framework with solutions to face these challenges. The one specific solution is to aware of the new generation by educating them to adopt a positive attitude to resolve the issues of conflicts. Keeping the above view there is a need for introducing peace education and Peace-building in the mainstream education system at all levels. The primary objective of the current study was to explore the perception of senior University teachers as internal stakeholders of education system regarding the need for Peace Education \& Peacebuilding in the mainstream education system at higher education level specifically. The selected population was public sector Universities of District Shaheed Benazirabad while the sample was thirty percent randomly selected senior teachers of three departments. The data was collected with the help of a questionnaire which was structured on the fivepoint Likert scale. The data were analyzed accordingly. The study revealed the different aspects of peace education and Peace-building. The findings recommended that high importance should be given to peace education in the mainstream education system.
\end{abstract}

Keywords: Peace education, peace-building, mainstream education system, integration, perception of stakeholders

\section{Introduction}

Internationally societies are encountering with different challenges ranging from cultural diversities to political tensions and religious to violent conflicts. It is a quite high time for human societies and its stakeholders to come up with the possible applied framework with solutions to face these issues and challenges. The best way to resolve these challenges is through educating the youth for constructive attitude to determine these issues of conflicts. Another very important strategy for a positive and nonviolent substitute for controlling conflict is peace education. There are various declarations of the United Nations about the consequences \& significance of peace education which also commemorated the International Day of Peace education.

\footnotetext{
* Tayyaba Zarif, Ph.D., Professor and Vice Chancellor, Shaheed Benazir Bhutto University, Shaheed Benazirabad, Nawabshah, Sindh

** Safia Urooj, Ph.D. Assistant Professor \& Incharge, Department of Teacher Education, University of Karachi

${ }^{* * *}$ Rizwana Munir, Ph.D. Assistant Professor \& Incharge, Department of Education, University of Karachi
} 
The main components of peace education \& Peace-building is teaching and learning of conceptual \& theoretical understanding of ethics, values, human rights, themes and skills, as the same time as the stakeholders have diverse perception about the concept and elements of peace education. ${ }^{1}$ Keeping in view the primary / general objective of current study was to explore the perception of internal stake holders of education system at higher education level specially regarding the need of Peace Education \& Peacebuilding in mainstream education system at all levels for the purpose opinion collected from senior University teachers as an internal stake holders.

Peace has intense effect on education and learning. Peace education facilitates youth to achieve knowledge, enhance their proficiency in the area of peace, and create an attitude about the perception of peace in human life. Peace education helps to prevent the emergence of disputations and forms environment for peace in the world. Hence peace education is very essential and peacemaking activities promote conflict resolutions which encourage peace and respect for human rights, freedom and assurance. United Nations celebrates every year worldwide International Peace Day on September $21^{\text {st }}$. The purpose of this day is strengthening the ideas of peace in all nations and culture regardless of race, color, religion and region. ${ }^{2}$

Between, 2006-2007 the UNESCO started the efforts to give the awareness about peace education for this purpose it sponsored the training programs by using the themes/content built up by the United Nations Refugee Agency (UNHCR) and endorsed by the Interagency Network for Education in Emergencies (INEE) the training programs targeted different stakeholders. ${ }^{3}$ As per the perception of the Organization:

Education for non-violence and peace includes training, skills, and information directed towards cultivating a culture of peace based on human rights principles. This education not only provides knowledge about a culture of peace, but also imparts the skills and attitudes necessary to defuse and recognize potential conflicts, and those needed to actively promote and establish a culture of peace and non-violence. ${ }^{4}$

Peace education strategies and programs differ country to country. Peace education and Peace-building learning process are effective and influential when incorporate with conventional schooling and education because education is the central social institution having larger impact on children and youth. Many countries have started the programs which integrate the elements of peace education and Peace-building as the subjects. South Asian region has continuously facing the war and terror hence countries of the region have started the peace sustaining programs such as Sri Lanka and Nepal have

\footnotetext{
${ }^{1}$ Koirala, B.N., A. Poudel, \& A. Khadka. Peace initiatives in Nepal: An assessment report. (Kathmandu: Save the Children of Sweden, 2010)

${ }^{2}$ I soraite, Margarita, The Importance of Education in Peace Marketing. Faculty of Economics, (Bangka: Belitung University, 2019). Internet resource. Access from https://mpra.ub.unimuenchen.de/91262/1/MPRA_paper_91262.pdf

${ }^{3}$ UNESCO. Lessons from integrating peace, human rights and civic education into social studies curricula and textbooks. (Paris, France: International Institute for Educational Planning, 2015): 7-9.

${ }^{4}$ UNESCO. UNESCO's Work on education for peace and non-violence: Building peace through education (Paris: UNESCO" 2008).
} 
introduced peace education and conflict resolution curriculum and guidelines for teachers promoting learning and sustaining harmony and peace. ${ }^{5}$

As time pass moral, cultural and modern values have deficient, transformed and promoting violence. There are five categories of peace that is moral, energetic, modern, post-modern and Trans rational peace. ${ }^{6}$ Epistemology, research and praxis regarding Peace education and concepts of peace and Peace-building are not given much importance and worthy. It is the emerging concept which indicates the factors and opportunities of development of society globally. ${ }^{7}$

Despite the long suffering of political crisis and war state of affairs in Pakistan like other South Asian countries, there is a raising interest to promote learning strategies and role of education about peace and conflict resolution regarding international concerns of stable and peaceful society and resolve the issues of insecurity, inequality and socio-economic problems. For this purpose there is a significant role of teachers, educators and facilitators of training in Peace-building and social integration. ${ }^{8}$

Research Objectives: The main Objectives of the study were:

$>$ To analyze the perception of stakeholders of mainstream education about key elements of peace education.

$>$ Find out the importance of the professional development of teachers about Peace-building

$>$ Explore the perception of stakeholders of mainstream education about integration of peace education in curriculum have the ways for enhancement of nonviolent attitude in education institutions.

$>$ Study the perception of stakeholders of mainstream education teaching of peace education as the mean of teaching values, ethics \& custom.

\section{Research Questions}

1. What are the perceptions of stakeholders of mainstream education about key elements of peace education?

\footnotetext{
${ }^{5}$ Manish Thapa, Raj Kumar Dhungana, Bhuvaneswari Mahalingam \& Jerome Conilleau, Peace by Piece: Mainstreaming Peace Education in South Asia (Stockholm: Save the Children Sweden, 2010).

${ }^{6}$ Dietrich, W. Many Peaces: Interpretations of peace in history and culture (New York: Palgrave Macmillan. 2012).

${ }^{7}$ Cremin, Hilary. "Peace Education Research in the Twenty-First Century: Three Concepts Facing Crisis or Opportunity?" Journal of Peace Education. 13, no. 1 (2016) 1-17.

${ }^{8}$ Sayed, Y., \& Novelli, M. The Role of Teachers in Peacebuilding and Social Cohesion: A synthesis report of South Africa, Uganda, Pakistan and Myanmar case studies. (University of Sussex: Research Consortium Education and Peace building. 2016)
} 
2. As per the perception of stakeholders of mainstream education how integration of peace education in curriculum have the ways for enhancement of nonviolent attitude in education institutions?

3. Is the professional development of teachers about Peace-building is need of time?

\section{Literature Review}

In this modern age of globalization, there are socio-economic and political turmoil and conflicts. Modification in lifestyle is a cause of increasing desires which shape a demanding attitude of people. It affects human life and disturbs the harmony in society. There are many views in different contexts about peace. Some intellectuals narrate the peace to the absence of war and some relate peace to the secure society and social justice. Harris, I. \& M. Morrison describes peace as:

Peace is a concept which motivates the imagination, connotes more than the cessation of war, implies human beings working together to resolve conflicts, respect standards of justice, satisfy basic needs and honor human rights.

From nineteenth-century social reforms were well considered a primary foundation for social change was provided by School, Religious Places \& Community groups. ${ }^{9}$ Due to education, learners contribute positively towards the development of society and also increase their hatred for violent attitude. In this regard, peace education also enables the students to act positively. ${ }^{10}$ Peace education produces a human realization and commitment to conduct harmony. ${ }^{11}$

Peace is the conceptual fact and universal requirement for everybody. Therefore everyone must try for establishing peace through formal and informal education. We can train our youth to make a peaceful environment. Peace education is to imbibe by techniques like knowledge, actions, skills, and values among students.

UNICEF has a relative approach in this regard:

Peace-building messages imparting human rights knowledge and values to children from their early age. This intensifies the Peace-building process by promoting a culture of peace and respect for human rights. ${ }^{12}$ The Integration of peace education in Teaching \& learning process actually facilitate the learners in their socialization that proceed towards responsible citizen. ${ }^{13}$

\footnotetext{
${ }^{9}$ Harris, I. \& M. Morrison. Peace Education (2nd. Edition) Jefferson, (North Carolina: McFarland \& Co .2003).

${ }^{10}$ Adeniji, I.A.A. Religious Conflict in Nigeria; A Ravaging Fire of our time: Being the Second Distinguished Before delivered at Federal College of Education, Abeokuta on Wednesday $26^{\text {th }}$ March, 2008.

${ }^{11}$ Banta, B."Peaceful Peoples: An Annotated Bibliography. (Metuchen, N.J: Scarecrow Press, 1993).

${ }^{12}$ UNICEF. "Nepal education in emergencies and post crisis transition: 2010 report evaluation. Kathmandu: UNICEF." $2011 \mathrm{~b}$.

${ }^{13}$ Adeniji, I.A.A. Religious Conflict in Nigeria. Op.cit.
} 
According to Jhon, Harris Ian and Synott peace education denoted to a training process for developing positive outlooks and behaviors amongst the individuals in the schools. ${ }^{14}$ Similarly Shruti also specified the same notion of Peace-building training for students. ${ }^{15}$

Jhon, Harris Ian and Synott, Shruti, A, also illustrated Peace education might have some dimensions such as educating people to control wars, development of tolerance, establishment of constructive angriness and disorder for global society, awareness of internationally accepted human individual rights for understanding and solving social discriminatory problems, resolution of conflicts, understanding democracy in its real sense, synchronizing international understanding, responsibilities to handle and understand environmental issues, accepting coexistence, equity and equality, while as spiritual dimension to respect to feelings, emotions and self-respect. They further identified the peace educational objectives such as enhance capacity and religious tolerance, positive behavior towards religious and moral values, creating lust for global knowledge and prudent thinking with open-mindedness, developing emotional attitude for co-existence and constructive attitude towards every human being and aware children, teenagers, youth and adults about universal humanity, justice and unfairness. ${ }^{16}$

The most important for peace education is its curriculum. The number of countries on the globe has developed a peace education curriculum; their curriculum is based on different curricular and co-curricular activities such as communication, coordination and complex problem-solving techniques. The researchers further concluded that peace education is as per the requirements of the human beings at their own levels, every individual has its own thinking level such as adolescence, adulthood, and old agers, all these levels have different understanding levels as well as their maturity levels. For peace education, according to the research study the prime purpose is to enhance skills of the individuals through teaching model, mediation, social and study camps and different sports and games. They further concluded that peace education is a conceptual reality and universal essence for every individual and that can be taught through formal and non-formal education system. The new generation in the schools and out of the schools can be trained for promoting peaceful surroundings through peace education. ${ }^{17}$

According to Harris, I.M \& Morrison, M. L peace education is meant to bring up human consciousness and determination to promote peace. It is as the physicians learn to how to treat patients in the hospitals and the students learn how to prevail peace and harmony on the earth sparing no room for social violence. Peace education is intended to nurture learners against the wrongdoings through teaching skills to resolve conflicts peacefully. If the doctors are against high expenses are train to treat the diseases then the students need to be trained to keep peace up for a harmonious environment on earth. The learners according to the researchers need to be provided extended knowledge as how to maintain

\footnotetext{
${ }^{14}$ Jhon, Harris Ian and Synott. "Peace Education for a new century." Social Alternatives 21, no. 1 (2002): 3-6.

${ }^{15}$ Shruti, A. "The Contemporary Issues And Significance Of Peace Education In India." IMPACT: International Journal of Research in Humanities, Arts and Literature 2, no. 10 (2014): 47-54.

${ }^{16}$ Ibid. pp.14-15

${ }^{17}$ Jhon, Harris Ian and Synott. Op.cit.
} 
peace in the universe, peace teachers should nurture a pedagogy based upon classroom practices on peaceful and democratic styles. ${ }^{18}$

The peace education ingredient is a temperament of kindness, critical thinking, and teamwork. To develop the above qualities according to the research study would develop peace not at a single stage but at individual and social levels as well. Peters, M.A. concluded that peace education and multi-culturalism are auspicious debates for nurturing peace education in either type of educational institutions and educational settings as now a days the word 'diversity' is being discussed for such purposes as well. ${ }^{19}$ Another study Mariappanadar, S. further stressed that peace education contents need to be included in teacher training manuals from lower to higher level institutions. ${ }^{20}$

The pre-service teachers highlighted nurturing essence to students' psychology in the teaching of peace education for rights of the women and avoidance of discrimination and non-tolerance behavior in the multicultural societies. Gurdogan-Bayir conducted a research study in war-affected countries on pre-service teachers, the pre-service teachers on the basis of their experiences narrated the reasons of peace and effects of wars, the political and financial interests, neighboring countries interests, the religious interests, ethical and moral discriminations are dominating factors of the conflicts. He further analyzed that essential point for effective teaching of peace education was given room all disagreements. The pre-service teachers on the basis of their war experiences claimed that wars could be the unsettled differences between two opposing parties. They further set it out that the teachers have the responsibilities and duties for peace education to nurture healthy minds and souls for peace and harmony. They further suggested that peace education should be imparted to the students from the very beginning of their learning and education process. ${ }^{21}$

The concise definition coined by prospective teachers in a study conducted by Polat, S., Arslan, Y., Günçavdı, G. the peace education was defined as an educational process nurtures common values such as reciprocal respect, love, tolerance equality and justice, etc. knowledge, attitude, and behavior. Peacemaking process must teach to the students in the school in order to resolve problems and conflicts between the individuals and the societies worldwide. ${ }^{22}$ According to Ubogu, R. even in the near past, it was assumed that the where there was no war there was peace. The extinction of war was supposed as a peaceful society. The above theory was a result of the consequences of the Second World War and the perception of the uncertainty of survival of human beings caused by the danger of nuclear war between two superpowers. The term "peace" is used as an abstract which is meant as a set of environmental and cultural values, traditions, manners, non-

${ }^{18}$ Harris, I.M \& Morrison, M. L. Peace Education, 2nd edition: Jefferson. N.C, (Mc Farland \& Co., 2003).

${ }^{19}$ Peters, M.A. "Education, post-structuralism and the politics of difference." Policy Futures in Education 3, no. 4 (2005): 436-445.

${ }^{20}$ Mariappanadar, S. An Emic Approach to Understand Culturally Indigenous and Alien. 2005.

${ }^{21}$ Gurdogan-Bayir, O., Bozkurt, M. "War, Peace, And Peace Education: Experiences and Perspectives of PreService Teachers." International Journal of Progressive Education 14, no. 1 (2018): 148-164.

${ }_{22}$ Polat, S., Arslan, Y., Günçavdi, G. "The Qualities of Teachers Who Instruct Peace Education: Views of Prospective Teachers' Who Attended the Peace Education Programme." Journal of Education and Practice 7, no. 28 (2016). 
violence attitude and means of life-based on respect for life. UN Charter of International law promotes practices of peace activities by imparting peace education, dialogue and cooperation, respect to territorial sovereignty and integrity, and political independence of States, and no insurgency in sovereign countries. ${ }^{23}$

The word 'peace' is a social concept represents the non-existence of violence, hostility, and war. They further described it as non-appearance of clash and conflicts which is regarded as the basis of social consistency and development of human societies. Giving respect to all human rights fostering conducive peaceful environment internationally, strategies should apply many commitments for settlement of conflicts peacefully, meet future needs of future generations, abidance of international principles of freedom, justice, democracy, tolerance, solidarity, co-operation, pluralism, cultural diversity, promoting peace dialogue and understanding at all levels in the society. Peace-building was a sound involvement to avoid the emergence of conflicts by generating durable peace. In the context of Nigeria peacemaking is related to economic and social justice while the development of positive human minds refers to a healthy society. Both descriptions of the word "peace" highlight the general human rights. Ubogu, R. also recommended that the public and private organizations should work together with researchers on diversified ways to nurture a culture of peace in the minds of the Nigerian citizens and the Government should present peace education at primary and secondary schools through its educational institutes as universal basic education. they further emphasized that Government should authorize youth at the grass root level to nurture Peace-building and peaceful culture in Nigeria. ${ }^{24}$

According to Nair, S.S., Dr., Nath, B.K., peace education is wide-ranging, interdisciplinary in nature and grips a wide range of programs and initiatives according to the peace education can be brought through environmental education, human rights education, international education, and developmental education. Different approaches to peace education looked upon "education is for peace" and "education about peace". The former is to create pre-requisites for the achievement of peace and later includes the practice and development of instructions and the way those involve a nonviolent social order. $^{25}$

Ebuara, V.O., Ekpoh, U, I., concluded that it was an invaluable requirement that the peace should exist in different higher educational institutions and different national and international organizations for growth, development and happiness at all spheres of life. ${ }^{26}$ It is further recommended that regular seminars, workshops and other such events on peace education should be arranged at all levels of educational institution especially at tertiary level institutions, an acceptable peace education educational model and relevant teaching material should be established and financial support to the institutions be

\footnotetext{
${ }^{23}$ Ubogu, R. "Peace Education in Secondary Schools: A Strategic Tool for Peace Building and Peace Culture in Nigeria ." Journal of Education and Practice 7, no. 14 (2016): 88-92.

${ }^{24}$ Ibid.

${ }^{25}$ Nair, S, S., Dr., Nath, B,K. "Integrating Principles of Peace Through Effective Transaction", 2009.

${ }^{26}$ Ebuara, V.O., Ekpoh, U.I. "Peace Management and Enhanced Academic Performance of Tertiary Institutions in South-South Nigeria ." Higher Education Studies 1, no. 2 (2011).
} 
provided to them by the government for better implementation of peace education in an effective way. ${ }^{27}$

A civil society organization named Global Partnership for the Prevention of Armed Conflict (GPPAC) are working on teachers skills, curriculum, information, strategies and training of students and teachers around the world observing peace education since 2006. It is an approach contributes in eliminating racism and discrimination. Education promoting peace is very important in the areas having anarchy and socio-economic fragile conditions. It emphasizes on social cohesion and building a harmony despite religious and cultural diversity. ${ }^{28}$

At the beginning peace education is not given high priority since 1989 - 2005, particularly in many agreements of internationally. ${ }^{29}$ However when countries gave concern and importance to post war strategies in the past it was also exist as physical defense strategy taught in educational institutions. ${ }^{30}$ This educational approach for peace and Peace-building in the society became the part of international community working for peace consider it as a widespread and universal issue e.g. Japan and Germany worked on the approach in post-World-War II. ${ }^{31}$ Internationally the approach of peace education began and integrated in education following with research and practice of Peacebuilding. 32

UN presented Agenda for Peace which is widely considered an authoritative document for generating peace agreements and Peace-building processes. It includes variety of activities practicing peace, involving programmes socio-economic development, humanitarian reforms and education for peace. ${ }^{33}$ According to Paris Global conflicts requires more reforms at macro level for sustainable Peace-building. ${ }^{34} 2030$ Agenda for Sustainable Development Goals (SDGs) comprises 17 SDGs and Goal 16 promote peace, justice and strong institutions. It aims to reduce and eliminate all forms of violence, discrimination and resolving conflicts and provide security to human rights. ${ }^{35}$ For this purpose a series of integrated approach have started for participation of Youth through

${ }^{27}$ Suryadi, B., Ekayanti., Amalia, E. "An Integrated Curriculum at an Islamic University: Perceptions of Students and Lecturers." Eurasian Journal of Educational Research , (2018), 25-40.

${ }_{28}$ Global Partnership for the Prevention of Armed Conflict (GPPAC), Internet resource Access from https://gppac.net/peace-education

${ }^{29}$ Save the Children Norway, "Building Peace Out of War: Children and Young People as Agents of Peace- The Young Generations Challenge" (paper presented at the International Conference, Oslo Norway, June 29-July 3, 2005).

${ }^{30}$ Marc Sommers, "Peace Education and Refugee Youth," in Learning for a Future: Refugee Education in Developing Countries, ed. Jeff Crisp, Christopher Talbot and Daiana B. Cipollone (Geneva: UNHCR, 2002), 163-216.

31 James Tent, Mission on the Rhine: Reeducation and Denazification in American-Occupied Germany (Chicago: University of Chicago, 1982).

${ }^{32}$ Kenneth D. Bush and Diana Saltarelli, The Two Faces of Education in Ethnic Conflict (New York: UNICEF, 2000)

${ }^{33}$ Suhrke, A., Wimpelmann, T., \&Dawes, M. ,Peace Processes and State-building: Economic and Institutional Provisions of Peace Agreements (Bergen,:World Bank \& UNDP, 08th February 2007)

${ }^{34}$ Paris, R., At War's End: Building peace after civil conflict, (Cambridge, UK: Cambridge University Press, 2004).

35 SDGF, Goal 16 :peace, justice and strong institutions Internet resource Access from http://www.sdgfund.org/goal-16-peace-justice-and-strong-institutions 
Peace education introduced in many countries in 2017, such as in Latin America peace education program introduced which enabling students learn skills of harmony, prevention from conflicts, indigenous culture, gender equality, issues about refugees IDPs. They experienced and gained firsthand knowledge creativity, Peace-building and constructive opinions about how to sustain peace. ${ }^{36}$

\section{Research Methodology}

The study was descriptive by nature and quantitative by method. The Population of the study was the senior teachers who are teaching at higher education level at district Shaheed Benazirabad.

There are three public sector Universities in said district so two universities were selected with the help of convenient random sampling. From each University, three departments were selected randomly as target population. From each department, from the list of senior faculty members thirty percent senior teachers were selected with the help of random sampling. The data was collected with the help of questionnaire which was structure on five point Likert scale. Items of tool developed on basis of three themes of research questions, theme one was key elements of peace education unfold in four sub themes theme two Integration of peace education in curriculum \& enhancement of nonviolent attitude unfold in three sub themes theme three was Need of Professional development of teachers about Peace-building. The data was analyzed with the help of percentage.

\section{Data Analysis \& Findings}

Items of tool were developed on the basis of three themes/ questions. The theme wise and sub-theme wise analysis is as under

\section{Research Question and Theme-wise Analysis}

Research Question No.1: What are the perceptions of stakeholders of mainstream education about key elements of peace education?

Item No.1, 2, 3 and 4 were for the answer of research question No.1 which was focused on theme No.1.

\footnotetext{
${ }^{36}$ Peace Boat-US, Peace Education and the Sustainable Development Goals in Latin America June 20 - July 3 , 2017, Internet resource Access from http://www.peaceboat-us.org/wp-content/uploads/2018/05/ProgramReport-94th-Voyage-SDGs-in-Latin-America.pdf
} 
Theme 1: key elements of peace education

Table1.1

\begin{tabular}{|l|l|l|l|l|l|l|}
\hline S\# & Sub Themes / Items & SA & A & UD & DA & SDA \\
\hline 1 & $\begin{array}{l}\text { Learning of Human Rights by Peace } \\
\text { Education }\end{array}$ & $64 \%$ & $20 \%$ & $10 \%$ & $4 \%$ & $2 \%$ \\
\hline 2 & $\begin{array}{l}\text { Peace education \& understanding about } \\
\text { themes, skills \& values }\end{array}$ & $60 \%$ & $32 \%$ & $5 \%$ & $2 \%$ & $1 \%$ \\
\hline 3 & Peace-building reduce violent attitude & $50 \%$ & $35 \%$ & $6 \%$ & $5 \%$ & $4 \%$ \\
\hline 4 & $\begin{array}{l}\text { Peace education is the mean of teaching } \\
\text { values , ethics \& custom }\end{array}$ & $85 \%$ & $10 \%$ & $4 \%$ & $1 \%$ & Nil \\
\hline
\end{tabular}

Graph No 1.1

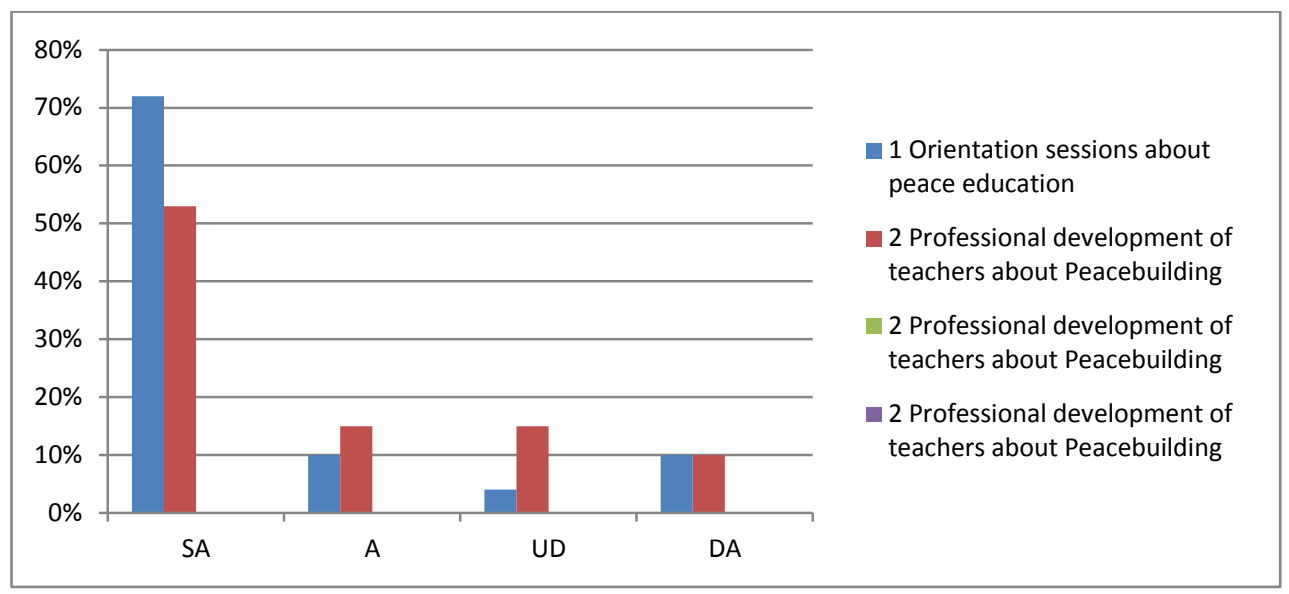

Keeping in view above Majority were strongly agreed about main theme regarding Key elements of peace education, 64 percent strongly agreed human rights as element, 60 percent strongly agreed about understanding of themes, skills \& values as key element of peace education while 85 percent strongly agreed that Peace education is the mean of teaching values, ethics $\&$ custom.

Research Question No 2: As per the perception of stakeholders of mainstream education how integration of peace education in curriculum have the ways for enhancement of nonviolent attitude in education institutions?

Item No. 5, 6, 7 and 8 were for the answer of research question No.2 focused on Theme No.2. 
Theme 2: Integration of peace education in curriculum\& enhancement of nonviolent attitude

Table1.2

\begin{tabular}{|l|l|l|l|l|l|l|}
\hline S\# & Sub Themes /Items & SA & A & UD & DA & SDA \\
\hline 1 & $\begin{array}{l}\text { Peace Education as a Goal in } \\
\text { curriculum }\end{array}$ & $45 \%$ & $34 \%$ & $15 \%$ & $4 \%$ & $2 \%$ \\
\hline 2 & $\begin{array}{l}\text { Peace Education as a course at higher } \\
\text { education }\end{array}$ & $40 \%$ & $20 \%$ & $14 \%$ & $20 \%$ & $6 \%$ \\
\hline 3 & $\begin{array}{l}\text { Peace-building as a Learning outcomes } \\
\text { at all levels }\end{array}$ & $56 \%$ & $18 \%$ & $20 \%$ & $04 \%$ & $02 \%$ \\
\hline 4 & $\begin{array}{l}\text { Integration of peace education in } \\
\text { curriculum \& enhancement of } \\
\text { nonviolent attitude }\end{array}$ & $65 \%$ & $20 \%$ & $8 \%$ & $5 \%$ & $2 \%$ \\
\hline
\end{tabular}

\section{Graph No 1.2}

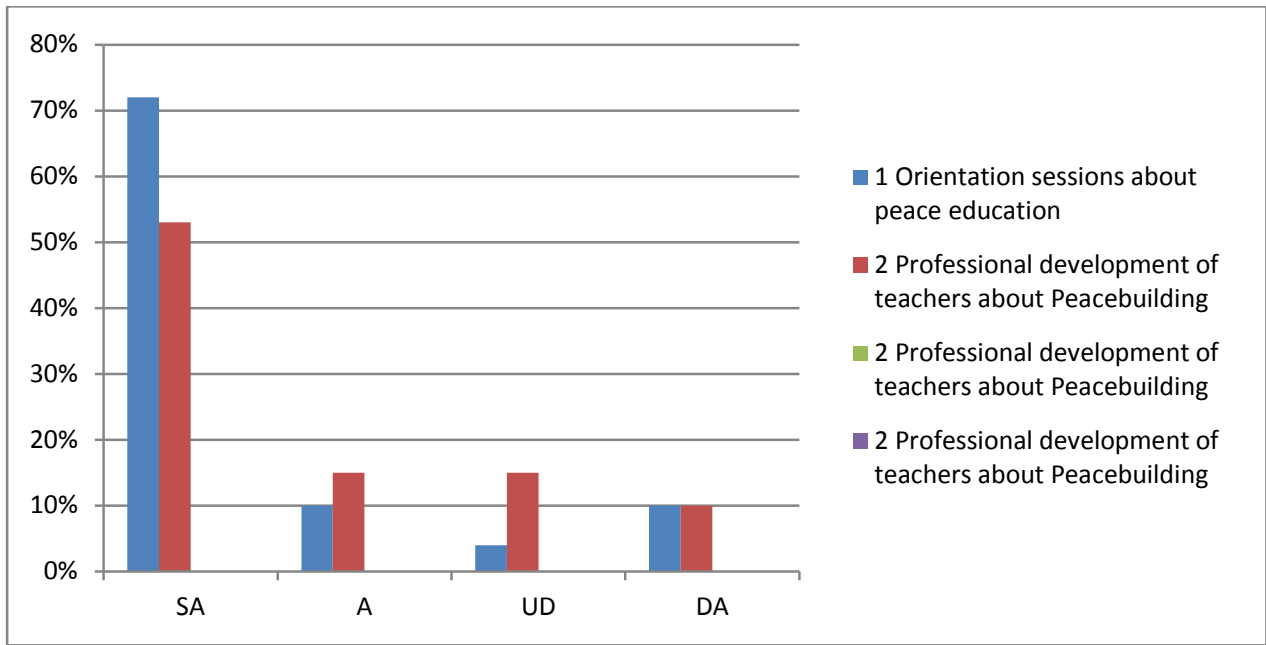

As per Above table Majority 45 percent, 40 percent, 56 percent and 65 percent were strongly agreed with all sub themes of theme Integration of peace education in curriculum\& enhancement of nonviolent attitude .

Research Question No 3: Is the professional development of teachers about Peacebuilding need of time?

Item No 9 and 10 were for research question No. 3 based on theme No.3. 
Theme 3: Need of professional development of teachers about Peace-building

Table 1.3

\begin{tabular}{|c|c|c|c|c|c|c|}
\hline S\# & Sub Themes / Items & SA & A & UD & DA & SDA \\
\hline 1 & $\begin{array}{l}\text { Orientation sessions } \\
\text { education }\end{array}$ & $72 \%$ & $10 \%$ & $4 \%$ & $10 \%$ & $4 \%$ \\
\hline 2 & $\begin{array}{l}\text { Professional development of teachers } \\
\text { about Peace-building }\end{array}$ & $53 \%$ & $15 \%$ & $15 \%$ & $10 \%$ & $07 \%$ \\
\hline
\end{tabular}

Graph No 1.3

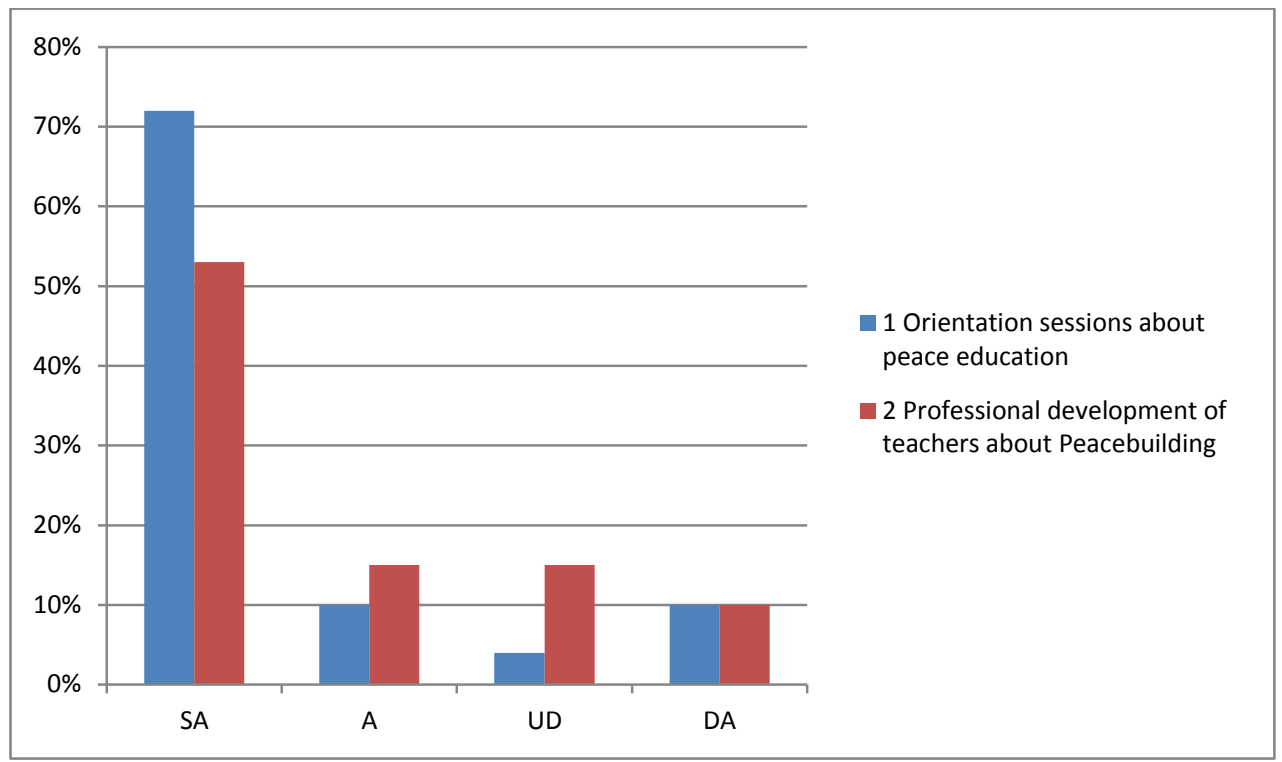

As per analysis majority 72 and 53 Percent strongly agreed that there is a need of professional development of teachers about Peace-building.

\section{Discussion and Conclusions}

The way is to aware the new generation by educating them about peace and harmony to accept positive attitude to resolve the issues of conflicts. This can be possible by Peacebuilding through peace education. Many Studies have given the idea about integration of peace through learning process and education. The current study focused on the Peace Education \& Peace-building in Mainstream Education System as per the perception of university teachers as an internal stakeholder. For collecting the answer of pointed out research questions a questionnaire was developed, items of tool developed on basis of three themes of research questions. Theme one was key elements of peace education unfold in four sub-themes theme two Integration of peace education in curriculum \& 
enhancement of nonviolent attitude, unfold in three sub-themes, theme three was need professional development of teachers about Peace-building to unfold in two sub-themes in this maximum strongly agreed. The majority are strongly agreed \& agreed about the mention areas as a Key element of peace education mean as per the perception of sample learning human rights, clarity about content, skills \& values are the main elements of peace education \& they are necessary for Peace-building. There is a need of necessary training and guidelines for teachers as well to teach their students and create a network for sustain the global peace. The majority are strongly agreed with the Integration of peace education in curriculum, ways for enhancement of nonviolent attitude as per sample include peace education as a goal of higher education in curriculum \& for achievement of developmental strategies including peace education as a course. It is concluded that there is a need for Professional development of teachers about Peacebuilding according to the perception of senior teachers, it is significant that institutions organize the awareness sessions about peace education which enhanced the Peacebuilding as well. The result showed that as per the perception of senior teachers' integration \& awareness of peace education \& Peace-building are very necessary at all level, especially at the higher education level. Peace education has its own level according to human desires. All people have their own cognitive level for instance old, adolescence and adult. Every person has a dissimilar understanding and maturity level. As every individual perceive the peace, harmony and satisfaction according to their own competence. Peace education is to imbibe by techniques like knowledge, actions, skills, and values in students. The overall conclusion is the peace education \& Peace-building should be integrated into the teaching \& learning process generally at all level of the mainstream education system and particularly at higher education level accordingly.

\section{Recommendations}

$>$ Peace Education Should be integrated in curriculum.

$>$ Learning outcomes about Peace-building should be part of curriculum at all levels

$>$ Professional development of teachers about Peace-building is need of time

$>$ Peace Education should be taught at higher education level as a course .

$>$ Learning outcomes about Peace-building should be part of curriculum at all levels

Integration of peace education in curriculum should enhancement of nonviolent attitude in education institutions 


\section{Bibliography}

Adeniji, I. Religious Conflict in Nigeria; A Ravaging Fire of our time: Being the Second Distinguished Before delivered at Federal College of Education, Abeokuta on Wednesday 26th March, 2008.

Banta, B. Peaceful Peoples: An Annotated Bibliography. Metuchen, N.J: Scarecrow Press. 1993.

Cremin, Hilary. "Peace Education Research in the Twenty-First Century: Three Concepts Facing Crisis or Opportunity?" Journal of Peace Education. 13, no. 1: (2016).

Dietrich, W. Many Peaces: Interpretations of peace in history and culture, New York: Palgrave Macmillan. 2012.

Ebuara, V. O. "Peace Management and Enhanced Academic Performance of Tertiary Institutions in South-South Nigeria". Higher Education Studies , 1 (2), 2011.

Gurdogan-Bayir, O. B. "War, Peace, And Peace Education: Experiences and Perspectives of Pre-Service Teachers". International Journal of Progressive Education , 14 (1), 2018.

Global Partnership for the Prevention of Armed Conflict (GPPAC), Internet resource Access from https://gppac.net/peace-education

Harris, I. \&. (2003). Peace Education (2nd. Edition) Jefferson, North Carolina: McFarland \& Co. 2003.

I soraite, Margarita, The Importance of Education in Peace Marketing. Faculty of Economics, Bangka Belitung University, 2019. Internet resource. Access from https://mpra.ub.uni-muenchen.de/91262/1/MPRA_paper_91262.pdf

James Tent, Mission on the Rhine: Reeducation and Denazification in American-Occupied Germany (Chicago: University of Chicago, 1982).

Jhon, H. I. "Peace Education for a new century". Social Alternatives , 21 (1), (2002).

Kenneth D. Bush and Diana Saltarelli, The Two Faces of Education in Ethnic Conflict (New York: UNICEF, 2000)

Koirala, B., Poudel, A., \& Khadka, A. Peace initiatives in Nepal: An assessment report. Kathmandu: Save the Children of Sweden. 2010. 
Marc Sommers, "Peace Education and Refugee Youth," in Learning for a Future: Refugee Education in Developing Countries, ed. Jeff Crisp, Christopher Talbot and Daiana B. Cipollone (Geneva: UNHCR, 2002), 163-216.

Manish Thapa, Raj Kumar Dhungana, Bhuvaneswari Mahalingam, and Jerome Conilleau, Peace by Piece: Mainstreaming Peace Education in South Asia. Stockholm: Save the Children Sweden, 2010.

Mariappanadar, S. An Emic Approach to Understand Culturally Indigenous and Alien. 2005.

Nair, S. S. \& Nath Baiju. Integrating Principles Of Peace Through Effective Transaction. 2009.

Paris, R., At War's End: Building peace after civil conflict, Cambridge University Press, Cambridge, United Kingdom, 2004.

Peters, M. A. "Education, post-structuralism and the politics of difference". Policy Futures in Education , 3 (4), 2005.

PeaceBoat-US,Peace Education and the Sustainable Development Goals in Latin America June 20 - July 3, 2017, Internet resource Access from http://www.peaceboatus.org/wp-content/uploads/2018/05/Program-Report-94th-Voyage-SDGs-in-LatinAmerica.pdf

Polat, S. A."The Qualities of Teachers Who Instruct Peace Education: Views of Prospective Teachers' Who Attended the Peace Education Programme". Journal of Education and Practice , 7 (28). 2016.

SDGF, Goal 16 :peace, justice and strong institutions Internet resource Access from http://www.sdgfund.org/goal-16-peace-justice-and-strong-institutions

Save the Children Norway, "Building Peace Out of War: Children and Young People as Agents of Peace- The Young Generations Challenge" (paper presented at the International Conference, Oslo Norway, June 29-July 3, 2005).

Sayed, Y., \& Novelli, M. The Role of Teachers in Peace-building and Social Cohesion: A synthesis report of South Africa, Uganda, Pakistan and Myanmar case studies. University of Sussex: Research Consortium Education and Peace-building, 2016.

Shruti, A. The Contemporary Issues And Significance Of Peace Education In India. IMPACT: International Journal of Research in Humanities, Arts and Literature , 2 (10), 2014.

Suhrke, A., Wimpelmann, T., \&Dawes, M. ,Peace Processes and Statebuilding: Economic and Institutional Provisions of Peace Agreements (Bergen,:World Bank \& UNDP, 08th February 2007) 
Suryadi, B. E. An Integrated Curriculum at an Islamic University: Perceptions of Students and Lecturers. Eurasian Journal of Educational Research , 2018.

Ubogu, R. Peace Education in Secondary Schools: A Strategic Tool for Peace-building and Peace Culture in Nigeria . Journal of Education and Practice , 7 (14), 2016.

UNESCO. Lessons from integrating peace, human rights and civic education into social studies curricula and textbooks. International Institute for Educational Planning Paris, France, 2015.

UNESCO. UNESCO's Work on education for peace and non-violence: Building peace through education. Paris: UNESCO. 2008.

UNICEF. Nepal education in emergencies and post crisis transition: 2010 report evaluation. Kathmandu: UNICEF." 2011 b. 